\title{
GLACIOLOGIGAL PROBLEMS SET BY THE GONTROL OF DANGEROUS LAKES IN CORDILLERA BLANGA, PERU. I. HISTORICAL FAILURES OF MORAINIC DAMS, THEIR CAUSES AND PREVENTION
}

\author{
By Lours Lliboutry, \\ (Laboratoire de Glaciologie du CNRS, Grenoble, France) \\ Benjamín Morales Arnao, \\ (Instituto de Geología y Minería, Lima, Peru) \\ André Pautre, \\ (Géoconseil, La Celle-St-Cloud, France) \\ and Bernard Schneider \\ (Coyne et Bellier, Paris, France)
}

\begin{abstract}
The retreat of glaciers since 1927 in Cordillera Blanca has produced dangerous lakes at the front of many glaciers. All the known data, most of them unpublished, are reviewed. The known aluviones are listed, and those of Chavín, Quebrada Los Cedros and Artesoncocha described in full. In these three cases a breach in the front moraine came from big ice falls into the lake. The protective devices made on the outlets are described, as well as the effects of the big earthquake on 3 I May r97o. In the case of Laguna Parón, which keeps its level thanks to infiltrations, the fluctuations of the discharge of the springs as related to the level of the lake from 1955 to 1969 are reported. The projects for lowering the level of Laguna Parón and for emptying Safuna Alta are described. The latter partially emptied in fact by piping after the earthquake, allowing a final solution.
\end{abstract}

RÉsumé. Problèmes glaciologiques soulevés par le contrôle de lacs dangereux dans la Cordillera Blanca, Pérou. I. Ruptures historiques de barrages morainiques, leur causes et leur prévention. Le retrait des glaciers depuis 1927 dans la Cordillera Blanca a créé des lacs dangereux au front de nombreux glaciers. On passe en revue tous les documents disponibles, la plupart non publiés. La liste des aluviones connus est établie, et ceux de Chavín, de la Quebrada Los Cedros et d'Artesoncocha complètement décrits. Dans les trois cas la brèche dans la moraine frontale fut la conséquence de grosses chutes de glace dans le lac. On décrit les ouvrages de protection faits sur les exutoires, ainsi que les effets du tremblement de terre du 31 Mai 1970. Dans le cas de la Laguna Parón, qui maintient son niveau grâce à des infiltrations, on donne les variations du débit des sources en fonction du niveau du lac entre 1955 et 1969 . On décrit les projets pour baisser le niveau de la Laguna Parón et pour vider Safuna Alta. Cette dernière se vida à moitié en fait après le séisme par formation de renards, permettant une solution définitive.

Zusammenfassung. Glaziologische Probleme bei der Uberwachung gefährlicher Seen in der Cordillera Blanca von Perú. I. Historische Brüche von Moränendämmen, ihre Ursachen, ihre Verhütung. Der Gletscherrückgang in der Cordillera Blanca seit 1927 hat zur Bildung gefährlicher Seen vor der Zunge vieler Gletscher geführt. Alle bekannten Daten, die meist noch unveröffentlicht sind, werden herangezogen. Die bekannten Ausbrüche (aluviones) werden aufgeführt, jene von Chavín, Quebrada Los Cedros und der Artesoncocha ausführlich beschrieben. In den drei Fällen führten gewaltige Eislawinen in den See zu Brüchen in der Damm-Moräne. Die Schutzmassnahmen an den Ausflüssen werden beschrieben, ebenso die Auswirkungen des grossen Erdbebens vom 3I. Mai 1970. Für den Laguna Parón, der sein Niveau infolge von Infiltrationen halten kann, werden die Änderungen der Quellschüttung im Vergleich zur Höhe des Seespiegels zwischen 1955 und 1969 zusammengestellt. Die Pläne zur Absenkung des Laguna Parón und zur Leerung der Safuna Alta werden beschrieben. Die letztere leerte sich in der Tat zur Hälfte nach dem Erdbeben durch Rohrleitungsbildung und erlaubte eine endgultige Lösung.

\section{Historical}

In this article and the two companion papers, field data collected in Cordillera Blanca, Peru, during the years 1967 to 1970 are reported. Since then they have been lying in drawers as unpublished and even restricted reports (Coyne et Bellier, Géoconseil, unpublished [a] to [e]; Lliboutry and others, unpublished).

In order to lower the water level in two dangerous lakes, Parón and Safuna Alta, the hydroelectric power agency of the Rio Santa basin known as Corporación Peruana del Santa, 
CPS (now united with other power agencies of Peru to form Electroperú), hired in 1967 as consultants two engineering offices, Coyne et Bellier and Géoconseil, from Paris. Parón was visited in February 1967 by Lliboutry, Morales, Pautre and Post; Safuna in July 1967 by Lliboutry, Morales and Pautre. From July 1967 to May 1969 , B. Schneider remained in the Callejón de Huaylas to supervise the workings (Callejón de Huaylas is the valley of upper Santa river, between Cordillera Blanca and Cordillera Negra). In May I969, the late J. Grador, with Lliboutry and Pautre, came back to Peru to study several lakes which may be used for hydroelectricity around Nevado Santa Cruz. This time they had at their disposal an Alouette III, the only helicopter able to fly at an altitude over 6 ooo $\mathrm{m}$.

Then the big castastrophe of 3 I May 1970 took place. Yungay and its 15000 inhabitants disappeared under the mud, $90 \%$ of the buildings of Huaraz were destroyed by the earthquake, $70 \%$ of Caraz and Carhuás. B. Morales and other engineers of CPS who were living in the Callejón were lucky to survive. On 9 and ro June Morales was able to fly in a helicopter over the main dangerous lakes, together with Lliboutry (who had been sent by UNESCO, on request of the Peruvian government). Also at the request of Peru, UNESCO and PNUD sent a commission to study possible sites for new cities. It was formed by B. Schneider, Professor V. Mencl from Brno and Dr M. Vallon from Grenoble. They remained in the area from August to October 1970, and among other surveys examined the dangerous lakes above Carhuás and Huaraz.

\section{Cartography and aerial coverages}

Until recently the only detailed map of the area were the two sheets at the scale of I : I oo ooo drawn from terrestrial photogrammetry in 1932 and 1939 and known as Kinzl's map.

During the Cordillera-Blanca Expedition des Deutschen und Österreichischen Alpenvereins 1932 (under the leadership of Dr Borchers), E. Hein, B. Lukas and H. Kinzl surveyed the northern part of Cordillera Blanca and Callejón de Huaylas between Nevado Champará and Huaraz. The corresponding sheet was published in 1935 in Die Weisse Kordillere (Borchers, editor). Explanations are given in Kinzl (1942). The bottom of many quebradas, specially the region of the Safuna lakes could not be plotted.

During the Anden-Kundfahrt des Deutschen Alpenvereins in 1939-40, K. Heckler and H. Kinzl surveyed the southern part. The sheet was printed in 1945 and included in the first issue of the Zeitschrift für Gletscherkunde und Glazialgeologie (1949). It was published again with explanations in Kinzl (1964).

Meanwhile aerial coverages of the Cordillera had been made. The United States Air Force (USAF) took trimetrogon pictures in 1943 and a single line of vertical photographs in I948 (project No. 3093). In 1948-50 the Servicio Aerofotográfico Nacional (SAN) of the Peruvian Air Force covered the Cordillera Blanca, using a camera of $23 \mathrm{~cm} \times 23 \mathrm{~cm}$, with a focal length of 6 inches (o.1 $524 \mathrm{~m}$ ) (project No. 2524). The altitude of flight was 27 ooo $\mathrm{ft}$ $(8230 \mathrm{~m})$. With these pictures an orthophotoplan at scale $\mathrm{I}: 20000$, and then a reduction at I : 142 ooo were made, on sale at SAN.

Under contract AST 9 of the Instituto Geográfico Militar del Perú (IGM), the USAF made a coverage of a great part of Peru in ${ }_{1962-63}$, using the same type of camera, and with a flight altitude of 30 ooo $\mathrm{ft}(9 \mathrm{I} 44 \mathrm{~m})$. It is now being plotted, simultaneously by IGM and by the Servicio Cartográfico del Ministerio de Agricultura para Reforma Agraria y Catastro, in order to draw maps at I : 25000 , but priority has been given to areas which do not include Cordillera Blanca.

Under contract from Corporación Peruana del Santa, the SAN made its own coverage of Cordillera Blanca in 1966-68 (Project No. 147-66-A), again with a focal length of 6 inches, (o. $1524 \mathrm{~m})$, and with 26 ooo ft $(7925 \mathrm{~m})$ as altitude of flight, and plotted it at scale $\mathrm{I}: 25$ ooo. 
It is an invaluable document, but with very poor drawing of the limits of glaciers, and available only as ozalid copies.

Thus for Safuna for instance we had at our disposal vertical stereoscopic pairs taken in 1950, I963, I 966 and 1968 . When the land is at an altitude of $4420 \mathrm{~m}$ and the flights were made at $30000 \mathrm{ft}(9 \mathrm{I} 45 \mathrm{~m}), 27000 \mathrm{ft}(8230 \mathrm{~m})$ and $26000 \mathrm{ft}(7925 \mathrm{~m})$, the scale of the contact pictures is respectively $\mathrm{I}: 3 \mathrm{I}$ 000, I : 25 000 and I : 23000 .

After the disaster, the Callejón de Huaylas and the western slopes of the Cordillera Blanca were covered by SAN (Project I76-70-A) and NASA ( $13^{-1} 8$ July i970, at 28 ooo ft $(8535 \mathrm{~m}))$.

\section{Formation OF LAKES ON GLAGIAL TONGUES}

With the exception of Huascarán Norte $(6655 \mathrm{~m})$, which had been climbed in 1908 by Miss Peck with two guides from Zermatt (R. Taugwalder and G. Zumtaugwald), all the summits of the Cordillera Blanca were virgin when the German-Austrian expedition of 1932 took place. They ascended nine summits, including the highest peak, Huascarán Sur 6768 $\mathrm{m})$. Thus there are no photographs prior to 1932 which may be used to study the variations of glaciers. The only quantitative data have been given by Kinzl (1942). On the eastern side of Cordillera Blanca, close to the Atlante mine, there is a small glacier (length: $2 \mathrm{~km}$ ), which flows northwards from Pakcharaju $\left(574 \mathrm{I} \mathrm{m}\right.$ ) to $5040 \mathrm{~m}$. It advanced by $12-15 \mathrm{~m}$ in $\mathrm{I}_{22} 3^{-24}$ and shut one entrance of the mine. It began to recede in 1927 . In 1932, when Kinzl visited it, its end was $45 \mathrm{~m}$ from the push moraine, and by 1939 it had receded about $60 \mathrm{~m}$ more.

This advance is almost synchronous with the one in the Alps in the years 1920-2 I. Almost all glaciers of Cordillera Blanca lay behind huge push moraines of the Little Ice Age which dam a lake. There are evident signs that glaciers reached these moraines again during this century (Lliboutry and others, I 977). Thus we may assert that the big and general recession of glaciers, which began in the Alps around I866, only began around 1923-24 in Cordillera Blanca. (Perhaps the apparent priority of the 1920-2 I advance in the Alps comes from the superimposed secular trend, which obliterated the effect of favourable balances in $192 \mathrm{I}-24$.)

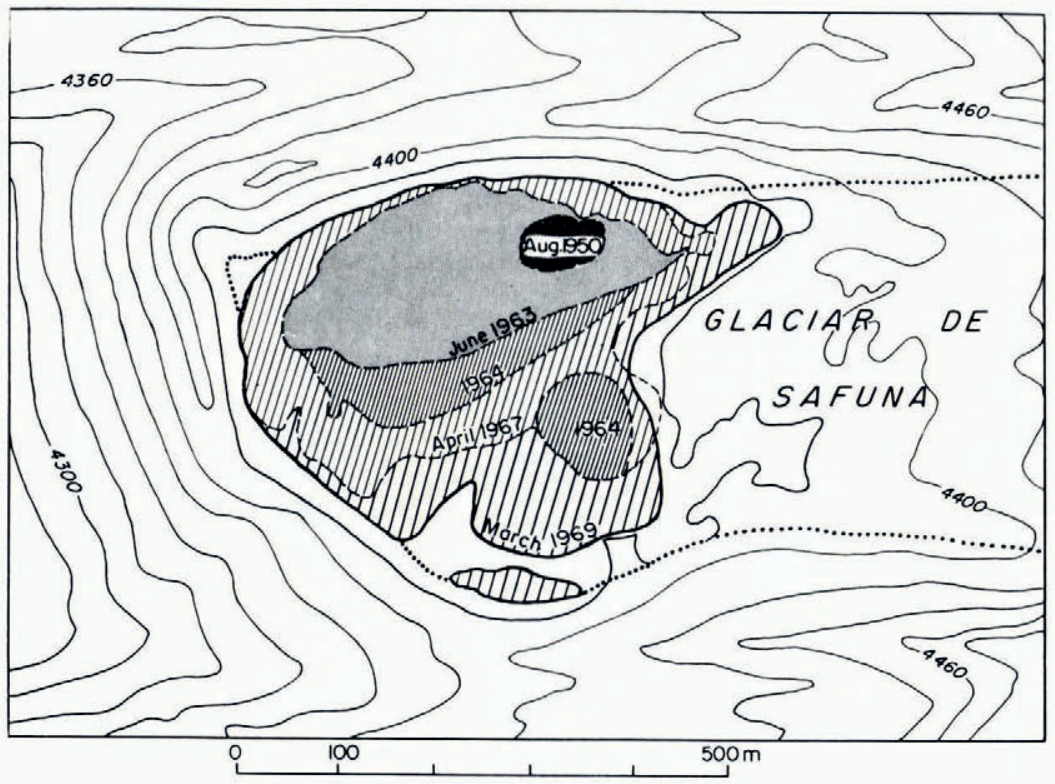

Fig. I. Development of Laguna de Safuna Alta. 


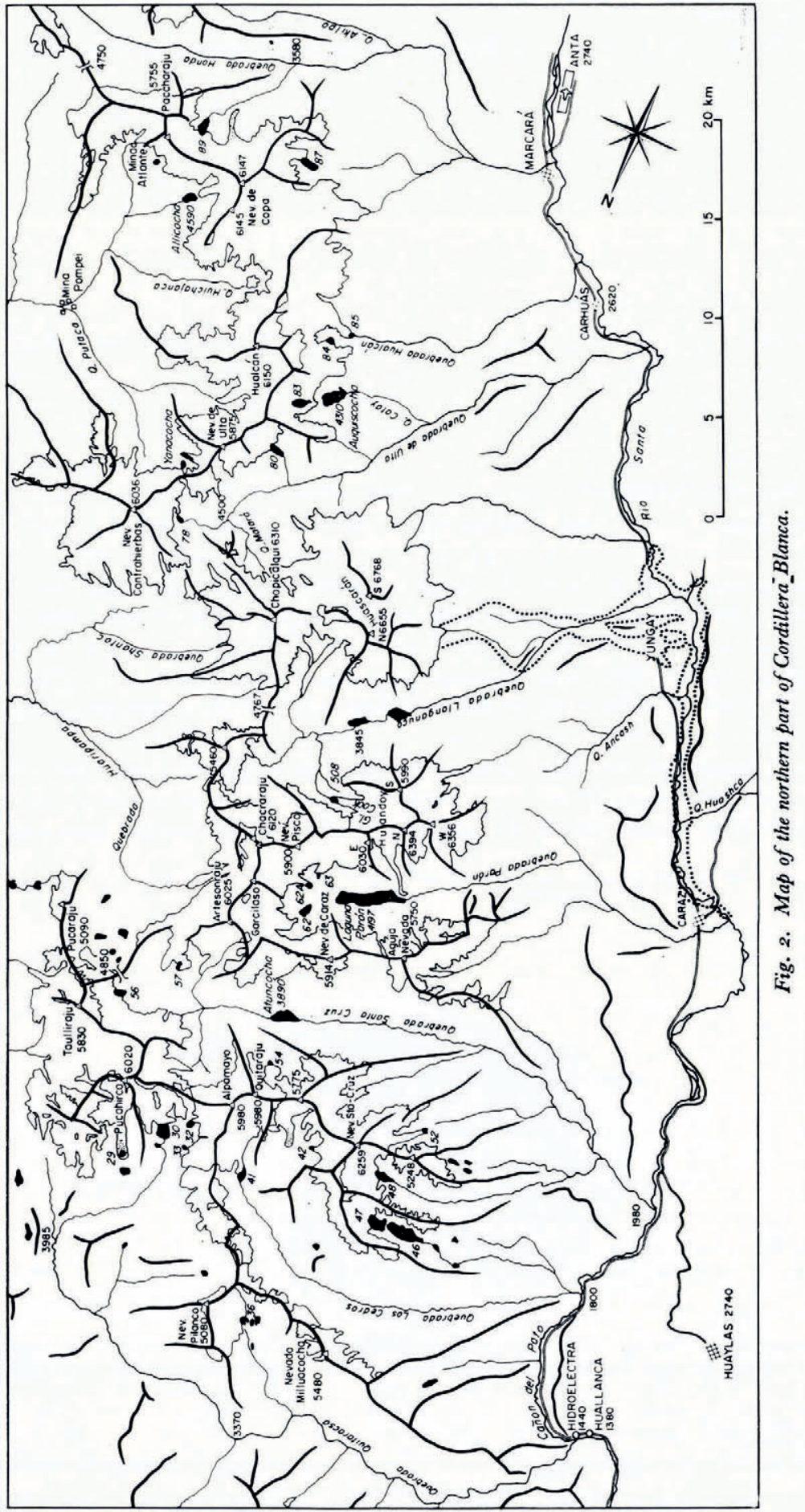


The recession of glaciers since $193^{2}$ has been considerable, but often its beginning would have passed unnoticed if the positions of the fronts had been surveyed each year, as is done in Switzerland and elsewhere. First one of several ponds of water appear in the tongue. They unite, enlarge, and a supraglacial lake is formed, which grows until it reaches the push moraine. With the proximity of sun-heated bare ground the process reinforces itself.

Figure I gives the evolution of Laguna de Safuna Alta. In I932, according to Kinzl (personal communication), there was no lake at all. In 1950 there was only a pool of water in a hollow of the glacier. On 19 March 1969 , we measured a volume of water of $4.85 \times \mathrm{IO}^{6} \mathrm{~m}^{3}$, which threatened the small town of Huallanca, $40 \mathrm{~km}$ down-stream. Its form was irregular because of the existence of a medial moraine, and the stream of ice on the left discharges more ice than the one on the right.

Between 1932 or 1939 (Kinzl's maps) and I948-50 (SAN photoplan), about ten big lakes appeared between Quebrada Ulta (over Carhuás) and Quebrada Shallap (over Huaraz): Lagunas Hualca, Cochca, Lejia, Paccharuri, Akilpo, Ishinca, Llaca, Tullparaju ... . (Laguna is Spanish; often the Quetchuan name cocha is used; thus we must say: Hualcacocha, Lejiacocha.) In the sketch map (Fig. 2), drawn from the SAN photoplan, these lakes are numbered according to the Comisión de Control de la Lagunas de la Cordillera Blanca (CCLCB). The main proglacial lakes of Cordillera Blanca are given in Table I, with all the data we could gather about them. In this table $193^{2-50}$, for instance, means that there was no lake in $193^{2}$ and there was one in $195^{\circ} ;<195^{\circ}$ means that the first picture available dates back to I950, and the lake existed at this time; > I950 that there was no lake in $195^{\circ}$, and there was one in 1961 ; $195^{\circ}$ that there was only a pond of water in $195^{\circ}$. The volumes in parentheses were those before the lakes were lowered.

After a proglacial lake has completely developed, new ponds of water may form up-stream on the glacier tongue. For instance Laguna Llaca, $400 \mathrm{~m}$ long, formed between 1939 and 1948. Between 1948 and 1968 , the glacier front did not recede, but four ponds of water, with surfaces from 100 to $2000 \mathrm{~m}^{2}$ appeared. Simultaneously there was a lowering of the whole glacier tongue, its surface turning from convex to concave (Lliboutry and others, unpublished).

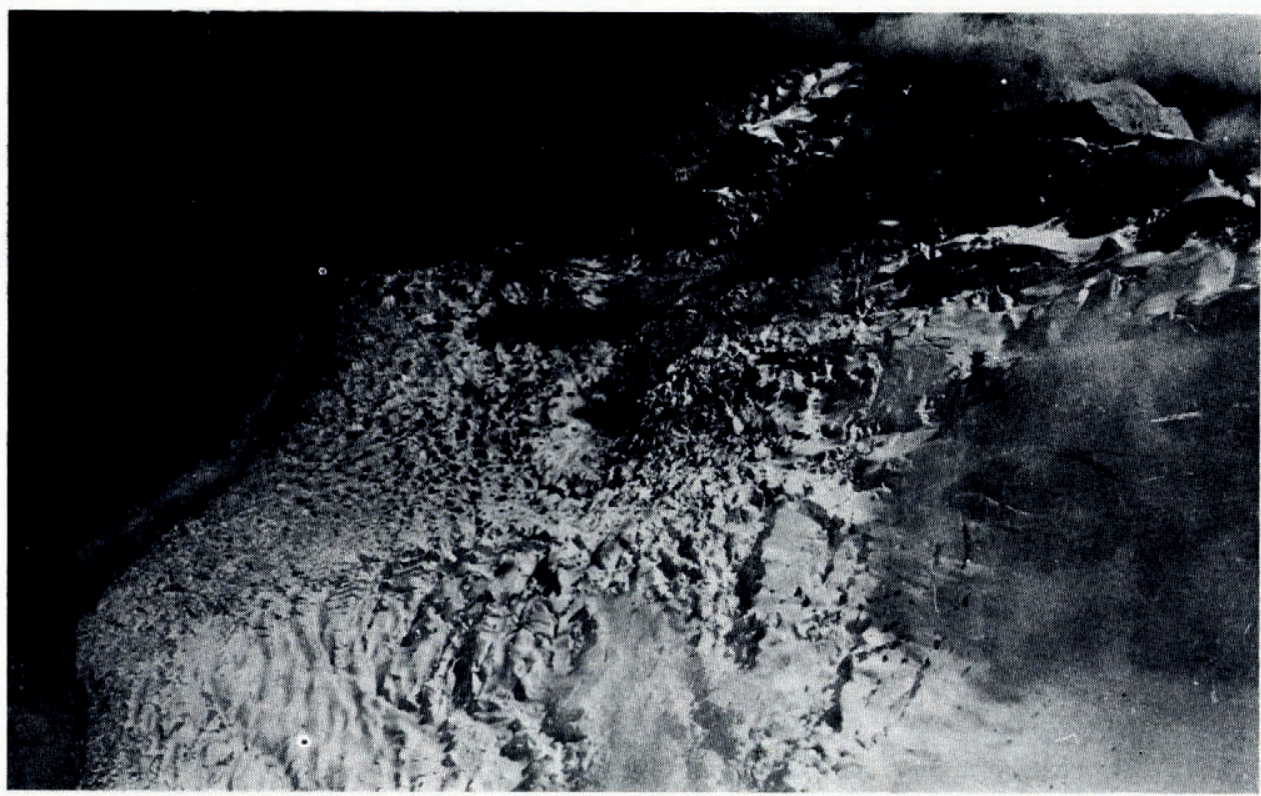

Fig. 3. Glaciar Kogan (north-east face of Alpamayo), with many small ponds of water on its tongue. Below (upper left), Laguna Jancarurish. (Picture from helicopter by L. Lliboutry, May 1969.) 
Table I. Proglacial lakes in Cordillera Blanca

Quebrada

$$
\begin{gathered}
\text { Quebrada } \\
\text { and (river) }
\end{gathered}
$$

Rio Santa Basin

Quitaracsa
Quitaracsa
Quitaracsa
Quitaracsa
Los Cedros
Los Cedros
Los Cedros
Yuraccocha
Santa Cruz
(Rio Yuracmayo)
Santa Cruz
(Rio Yuracmayo)
Santa Cruz
(Rio Yuracmayo)
Parón
(Rio Llullán)
Parón
(Rio Llullán)
Parón
(Rio Llullán)
Llanganuco
Llanganuco
Ulta
(Rio Buin)
Ulta
(Rio Buin)

Catay

Hualcán

Hualcán

Hualcán

Honda

(Rio Marcará)

Honda

(IRio Marcará)

Akilpo

Ishinca

(Rio Lucma)

Mullaca

Llaca

(Rio Casca)

\section{Cohup}

Quilcayhuanca

(Rio Quilcay)

Quilcayhuanca
(Rio Quilcay)

Shallap

Rajucolta

(Rio Paria)

Rurec

Rio Marañon basin

Putaca

Allipampa
Location

N.W. Pucahirca

W. Pucahirca

N.E. Alpamayo

E. Jancarurish

(N. of Alpamayo)

N.W. Alpamayo

(Glaciar Kogan)

W. Nevado Santa Cruz

N.W. Nevado Santa Cruz

W. Nevado Santa Cruz

S. Quitaraju

S.W. Taulliraju

N. Nevado de Caraz

S. Artesonraju

N.W. Chacraraju

N. Nevado Pisco

S. Chacraraju

E. Huandoy

(Glaciar Cook)

W. Nevado

Contrahierbas

N. Chequiaraju

S.W. Chequiaraju

W. Hualcán

W. Hualcán

S.W. Nevado de Copa

S.W. Paccharaju

W. Tocllaraju

N. Ranrapalca

W. Jangyaraju

S.W. Ranrapalca

W. Pucaranra

S. Pucaranra

S.W. Nevado Chinchey

W. Nevado San Juan

I 1

L. Shallap

W. Huantsán

N.W. Uruashraju

123

134

L. Rajucolta

L. Tararhua

$4275<1939$

$4480<1939$

S. Nevado Contrahierbas

E. Nevado de Copa
326

L. Yanaraju

336 Allicocha
Formed Volume Altitude A.D. in 1974 $\times 10^{6} \mathrm{~m}^{3}$

werks by CCLCB, CPS and Electroperú 
Many ponds of water have appeared on Glaciar Kogan, well above Laguna Jancarurish (Fig. 3).

The glacier ending in Laguna Tullparaju receeded by $300 \mathrm{~m}$ between 1950 and 1962 , but no change was seen between 1962 and 1970 (Lliboutry and others, unpublished). Laguna de Safuna increased on one side but there was almost no change on the strongest stream of ice. Thus it seems that the recession of glaciers reached its climax and is decreasing.

\section{KNOWN ALuviones}

An aluvión (plural: aluviones) is a very big and sudden flood of liquid mud, generally carrying big boulders, whatever may be its cause. A Quetchuan name is huayco, which is used for muddy floods of any size. Aluviones are the plague of the fertile and heavily populated Callejón de Huaylas.

The biggest ones have come from huge rock and ice avalanches starting from the top of Huascarán Norte: in this way Ranrahirca was drowned on Io January I 962 with 4 ooo dead (B. Morales, I966); Ranrahirca and Yungay on 31 May 1970 with I 5 ooo dead (Welsch and Kinzl, 1970; Plafker and others, I971; Lliboutry, [1975]). These avalanches eroded the firn of Glaciar 5i I below; next they eroded warm loose earth which melted ice and firn. In this way a liquid mud was formed, but no lake was involved.

The first historical record of an aluvión, by Th. Haenke in Descripción del Perú (Lima, I9or), a book which we could not consult, happened on 6 January 1725 (in Kinzl, I968, I625 is quoted, which is a misprint, cf. C. Morales, I968). The village of Ancash, close to Yungay and north of it was destroyed and its I 500 or 2000 inhabitants killed by an aluvión coming from Huandoy. Aerial photographs show that it was undoubtedly formed by the destruction of a lake at the head of Quebrada Ancash.

There was no aluvión reported again in the Cordillera Blanca until the year 1938, when, on 20 January, one occurred in Quebrada Ulta, without loss of lives (Kinzl, I940). It came from the rupture of Pacllashcocha, better known under the name of Laguna Artesa. (A previous one, in 1930, reported in CPS, unpublished, seems to be an error.) Nevertheless, according to V. M. Philipps*, there was one on 14 March 1932 in Cordillera Huayhuash, just south of Cordillera Blanca. It came from the rupture of Laguna Soltera, or Huancacocha, in Quebrada Pacllón.

Next, on I 3 December 194I, came the disaster of Huaraz which destroyed one-third of this city, killing more than 6 ooo inhabitants. The aluvion was caused by the rupture of Palcacocha, in Quebrada Cohup. After this disaster the Comisión de Control de Lagunas de la Cordillera Blanca was set up, which began to lower the level and strengthen the outlets of the most dangerous lakes, as we shall explain later.

On I 7 January I945 the small town of Chavín de Huantar (today: Chavín arqueológico), on the eastern side of Cordillera Blanca was destroyed by an aluvión coming from Quebrada Huachescsa down-valley of Huantsán $(6395 \mathrm{~m})$. There were many dead, among whom were the prefect of the province of Ancash, and invaluable archaeological material was lost. Chavin had indeed been the main centre of the first great civilization in Peru. Its temples and castles have been dated 850 B.c. by ${ }^{14} \mathrm{C}$ (Kauffmann, I973, p. 180, 203). We may assert then that there were no aluviones in Chavín during those times.

According to Spann (1947), who visited the area eleven months later, the aluvion was produced by a big rock-fall from Huantsán on the debris-covered glacier at its foot. His guide told him that there were formerly "some lakes and swamps (pantanos) known as Laguna de Ayhuiñaraju". (Ayhuiñaraju is the local name of Huantsán on its eastern side.) When one of us (B.M.) visited the area, he saw a lake almost emptied by the ice fall, but still $150 \mathrm{~m}$ long,

\footnotetext{
* In a popular account on aluviones published in 1962 in No. 24 of Ingeniería (Lima).
} 
with its destroyed morainic dam. The swamp which was swept down is found half a kilometer down-valley.

On the aerial views taken three or five years later, this event is hardly noticeable, the lake being infilled with ice. It lies on the right of the main and covered glacier tongue and $200 \mathrm{~m}$ higher, at about $4800 \mathrm{~m}$. The rock-fall came from the southern summit of Huantsán, on another glacier, a clean one.

Lower down the valley, the trace of the aluvion cannot be clearly seen, until the last $7 \mathrm{~km}$ before Chavín. It is then at most $50 \mathrm{~m}$ wide. There is a big difference with the aluvión of Huaraz which, although three years older, appears as the most striking feature of the same aerial coverage.

On 20 October 1950, Laguna Jancarurish was destroyed during the workings of the CCLCB to lower its level. The aluvión which flowed down Quebrada Los Cedros killed perhaps 500 people, although 200 are mentioned in official reports.

Artesoncocha, behind Laguna Parón, was destroyed twice, on I 7 July I95 I and 29 October I95I, without producing any damage down-valley, as explained later.

Other ruptured lakes may be seen on the aerial photographs of $194^{8-50}$ : on the eastern glacier of Huascarán (Quebrada Matará, a tributary of Quebrada Ulta), at about $445^{\circ} \mathrm{m}$; on north-east of Chopicalqui, in Quebrada Shantoc, at about $44 \mathrm{IO} \mathrm{m}$; Allicocha, on the eastern side of Cordillera Blanca; and behind Laguna Parón, Chacrucocha, which we were able to visit in 1967 (Fig. 4).

The big earthquake of 31 May i 970 did not lead to the destruction of any morainic dams on the western side of Cordillera Blanca, but this was not true on the eastern side. Yanacochachica, in Quebrada Putaca, and a lake at the head of Quebrada Huichajanca emptied, both flooding the Pompei mine.

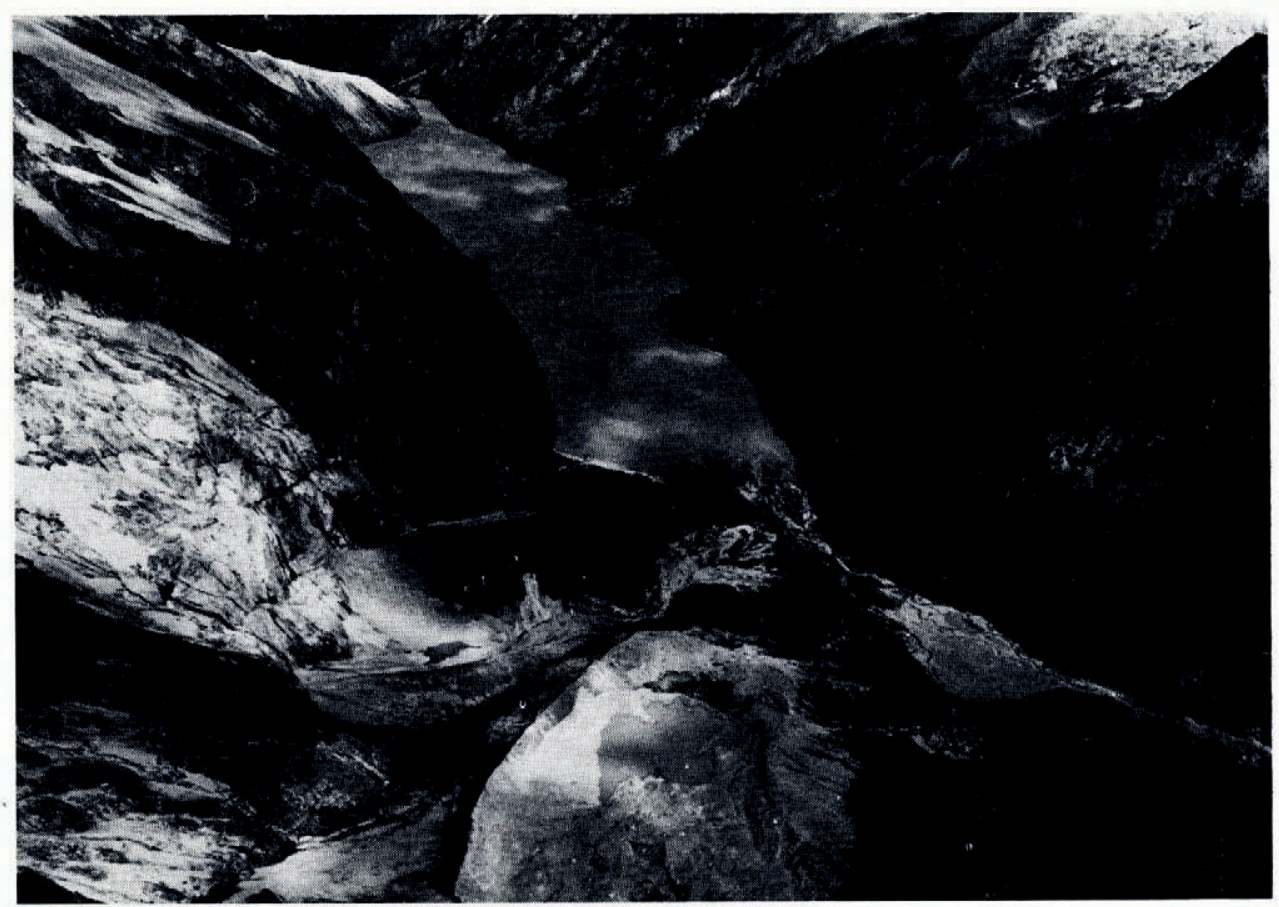

Fig. 4. Laguna Parón from the east. In the foreground, from left to right: Chacrucocha emptied by a breach in the morainic dam, lake 69, and the aluvial fan resulting from the rupture of Artesoncocha. (Picture from helicopter by L. Lliboutry, May ig69.) 
What an aluvión looks like. Morphological gonsequences

Ghiglino (unpublished) has given a precise description of the aluvion in Quebrada Los Cedros, in 1950. Its average velocity in the Quebrada, $20 \mathrm{~km} \mathrm{long,} \mathrm{and} \mathrm{Cañon} \mathrm{del} \mathrm{Pato,}$ was $33 \mathrm{~km}$ per hour, much lower than the Huascarán avalanche (which covered I $3.8 \mathrm{~km}$ at an average velocity of over $36 \mathrm{om} / \mathrm{h}$ ), but much faster than ordinary mudflows. The wetted section varied, according to the slope, between 400 and $2300 \mathrm{~m}^{2}$. The flow rose at bends of the valley, on the concave slope, up to $24 \mathrm{~m}$ in the lower Santa Valley at $123 \mathrm{~km}$ of the railroad from Chimbote. The average discharge was estimated by Ghiglino to be 7 ooo- 8 ooo $\mathrm{m}^{3} / \mathrm{s}$, the volume of water involved at $2 \times \mathrm{IO}^{6} \mathrm{~m}^{3}$, although 6 to $10 \times 10^{6} \mathrm{~m}^{3} \mathrm{seem}$ more credible, as explained below. The volume of alluvium deposited in the bed of Rio Santa was estimated at $3 \times 10^{6} \mathrm{~m}^{3}$, which seems also to be a conservative figure. In places the deposit was $2 \mathrm{~m}$ thick, and one dam as much as $45 \mathrm{~m}$ high was formed, but in other places the soil was eroded down to a depth of $6 \mathrm{~m}$.

As an example of the ability of such an aluvión to transport big boulders, a $5 \mathrm{~m} \times 7 \mathrm{~m} \times 25 \mathrm{~m}$ concrete bridge pillar, weighing $2000 \mathrm{Mg}$, was carried $20 \mathrm{~km}$ down the valley.

Eye-witnesses said that first an avalanche of solid material appeared. A few seconds later black mud appeared between the stones. Progressively it turned into a muddy stream, running between two raised, very slowly moving, levees. 50 min after beginning, the solid discharge was still $30 \%$.

With such descriptions in mind, to walk in the break of the frontal moraine through which a lake has emptied, as at Chacrucocha, is an impressive experience. A brooklet now trickles on an avenue of pebbles, 20 to $30 \mathrm{~m}$ wide, between two vertical earth cliffs about $50 \mathrm{~m}$ high. Down-stream, in the case of a local event such as this one, there is an aluvial fan without sorting, a typical sandur. Many fans in former glacial valleys, previously considered as the result of progressive construction by streams, should in fact be considered as the result of such catastrophic events at the end of the ice age, as proved by the presence of unsorted big boulders embedded at random within them.

\section{FAILURE OF MORAINIC DAMS WITH OPEN-AIR OUTLETS, AND THEIR PREVENTION}

The young morainic dams of Cordillera Blanca, as elsewhere, are formed by a mixture of angular debris of any size, sand and silt, with very little clay. In many parts layers of silty sand and gravel, without any big boulders are found. In Figure 5 the distribution function of the sizes in samples from the moraine surrounding Laguna de Safuna Alta are drawn. There is about $10-15 \%$ of fine sand, silt and clay with $\varnothing<0.2 \mathrm{~mm}$ and $30-50 \%$ of pebbles and boulders with $\varnothing>2 \mathrm{~cm}$. Thus most moraines are pervious and even when there is an open-air outlet, springs are found at their foot.

In the case of an open-air outlet, the cutting of the unconsolidated dam by regressive erosion is the obvious process which unlatches the aluvión. Nevertheless the initial cause of the starting of this rapid erosion has been controversial. All the aluviones which are exactly dated, with the exception of Los Cedros and Artesoncocha, took place during the rainy season which extends from October to April in Cordillera Blanca They are (not including Chavín):

Huaraz: i 3 December

Ancash: 6 January
Ulta: 20 January

Pacllón: 14 March

Nevertheless we do not know if there was an open-air outlet in every case.

On the other hand in two well-known cases, Los Cedros and Artesoncocha the disaster came (and in a third case, Tullparaju, it might have come) from big waves which overflowed the free-board, following big ice falls into the lake. 


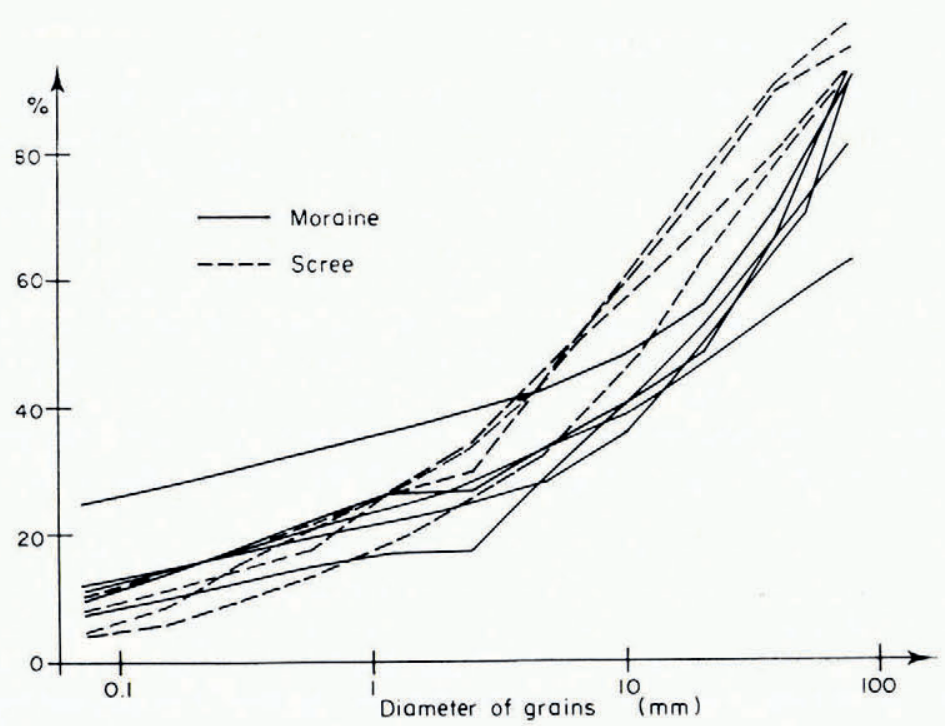

Fig. 5. Grain sizes from cores of the moraine of Safuna Alta, and from its veneer of scree.

Artesoncocha (Fig. 6) which appeared between 1932 and 1940 , was $500 \mathrm{~m}$ long, $250 \mathrm{~m}$ wide, and $50 \mathrm{~m}$ deep (Kinzl and Schneider, 1950) in 1948. It is overhung by seracs which regularly fall into the lake. The trace of the waves is clearly seen on the inner (today raised) beach at the other end. The dam has been destroyed twice, and we have a precise description of the events (CPS, unpublished). During the night between 16 and 17 July I95 $\mathrm{I}$, an icefall estimated at 4-5 million cubic metres produced a first leakage of the morainic dam. The level of the lake was lowered by $7 \mathrm{~m}$, with the escape of I.I3 million cubic metres of water, which raised the level of Laguna Parón by $0.70 \mathrm{~m}$. A waterfall, $22 \mathrm{~m}$ wide was formed on the external side of the dam, and regressive erosion caused its final rupture, three months later. This time $3.5^{2}$ million cubic metres of water escaped, raising the level of Laguna Parón by $2.0 \mathrm{~m}$. Fortunately these events happened during the dry season, when Laguna Parón (which has no open-air outlet) was at a low level. If it had happened during the rainy season, an aluvión would have flooded the town of Caraz.

In order to avoid such events, the CCLCB, with the aid of CPS, has been consolidating the open-air outlets since $194 \mathrm{I}$, and even lowering the level of the most dangerous lakes. (In 1970 this commission was included in the CPS.) The protective works which have been completed are indicated in Table I.

When the free-board seems insufficient, the level is progressively lowered, $20 \mathrm{~cm}$ after $20 \mathrm{~cm}$, by means of a trench. Finally the trench is protected by a sole of concrete, or a large pipe is put at its bottom. On both sides of the mouth of this artificial outlet, the free-board is protected by a pavement of stones or two slabs (called aletas, i.e. small wings) of concrete. The works are completed by an earth dam io to $20 \mathrm{~m}$ high (B. Morales, i969; Electroperú, unpublished).

The big earthquake of 1970 broke many aletas by settling the moraine below (for this reason stone pavements seem better), and filled in many open-air ducts with debris (so pipes seem better) but did not start any aluvión where protective works had been done. Thus this device has proved to be efficient.

Nevertheless the construction of the duct and the lowering of the lake is a hazardous enterprise as shown by the two following case histories: 


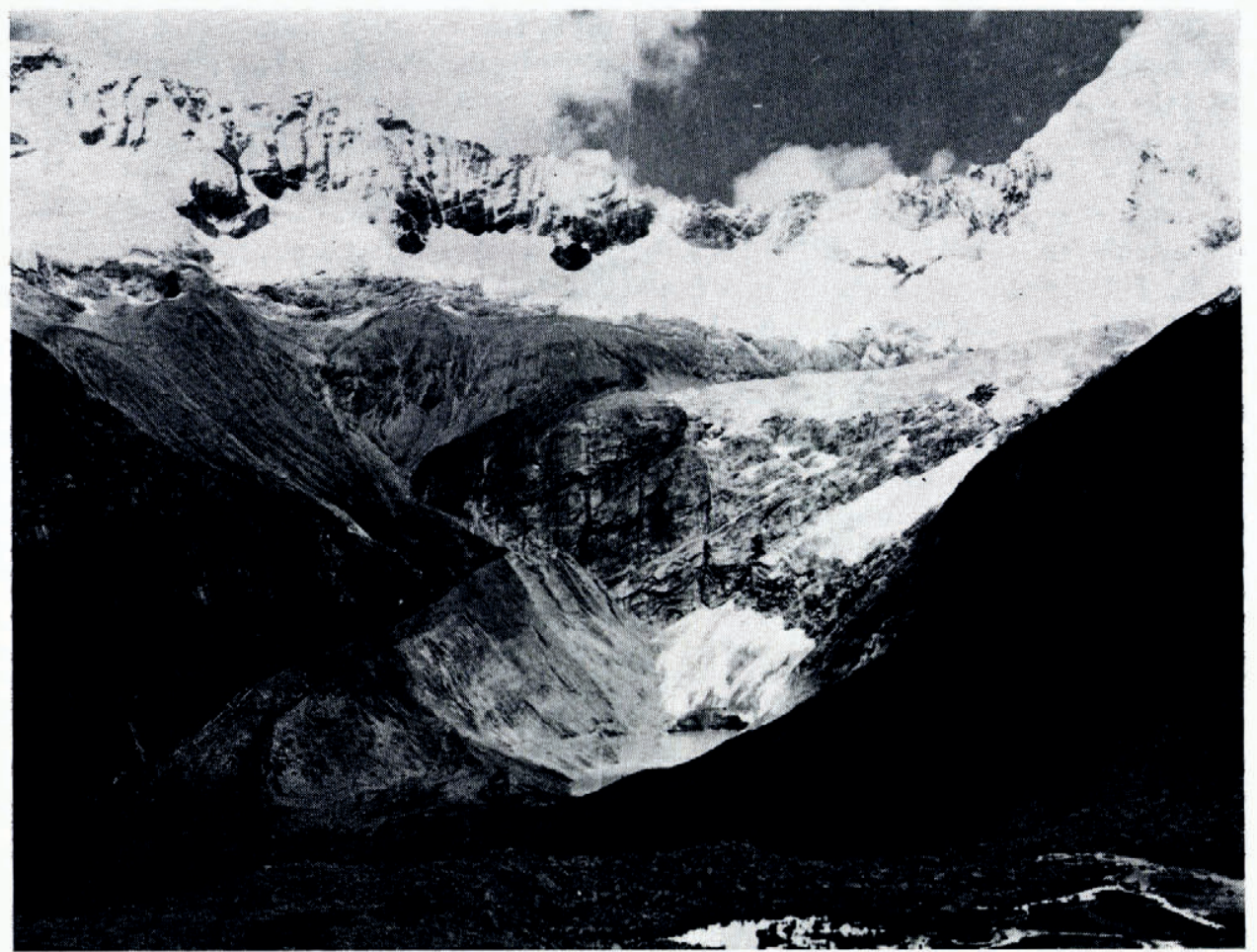

Fig. 6. Artesoncocha on 4 February 1967, seen from lake 69. At the upper right corner, Artesonraju.

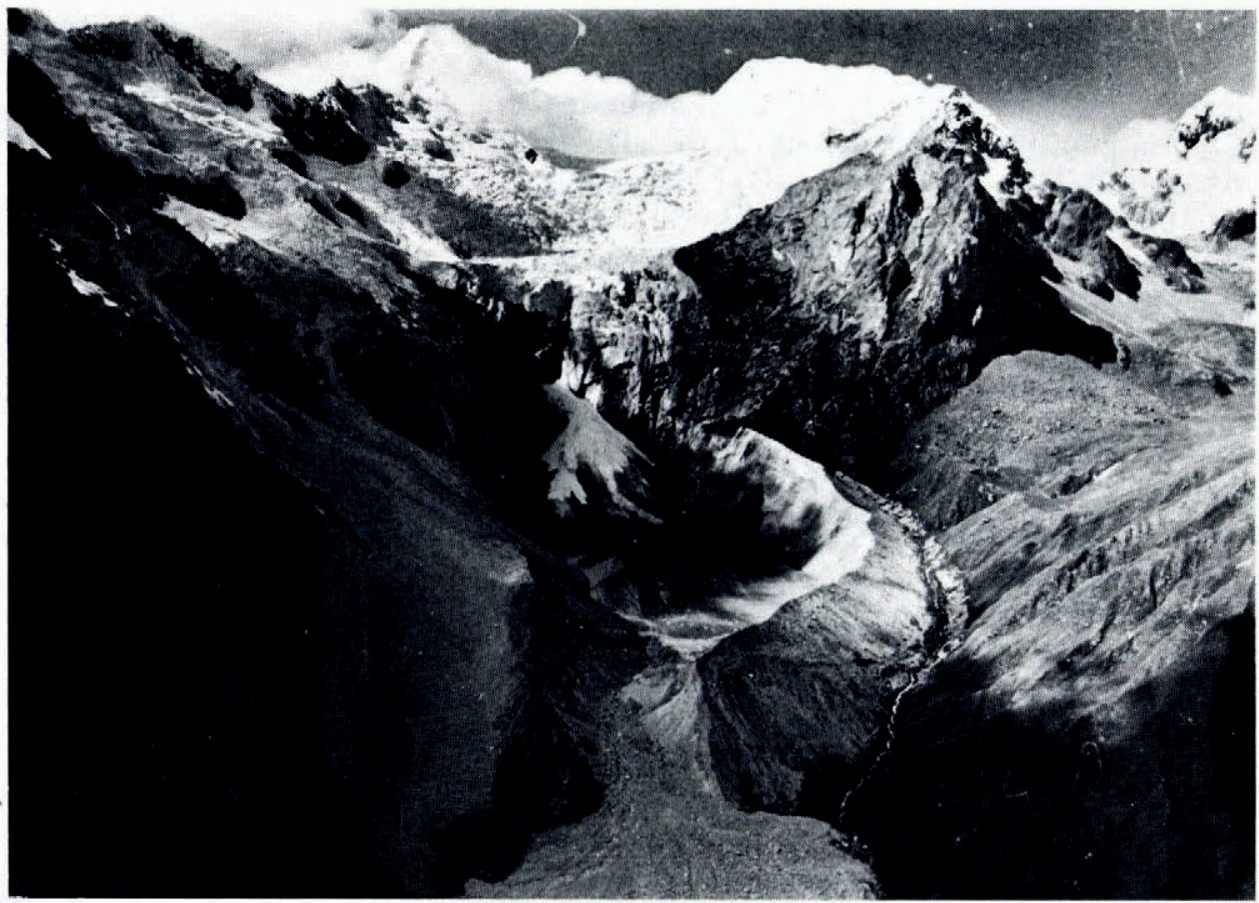

Fig. 7. Laguna Jancarurish, below Glaciar Kogan and Alpamayo. (Picture from helicopter by L. Lliboutry, May 1969.) 
In 1953, during the lowering of Laguna Tullparaju, an earth slide on the left bank of the lake raised a $12 \mathrm{~m}$ high wave which poured into the trench which had already been dug. The leakage which started was fortunately stopped, after a lowering of the lake by $18 \mathrm{~m}$, thanks to some beds of black glacial clay present within the moraine, and to the sandbags thrown in by the workers.

Laguna Jancarurish, in Quebrada Los Cedros had an underground discharge. The freeboard was only $10 \mathrm{~m}$ in the middle of the front discharge. It seemed insufficient, since ice avalanches fall continuously into the lake from Glaciar Kogan, forming a regenerated glacier, a big ice apron at the head of the lake (Figs. 7 and 8). In 1949 the CCLCB began to lower the lake by cutting this free-board, digging a trench to lower the lake a little, then closing the mouth and digging the trench a little deeper, and so on. After two years work, the lake had been lowered $15 \mathrm{~m}$. Under the precarious protection of a wooden gate $2 \mathrm{~m}$ high, the trench has been deepened two metres more, and a sole of cemented stones was under construction when an unexpected event happened. (In fact Dr Ali Szepessy Schaurek, in a report of 30 January 1950, has put the CPS on its guard against this hazard (Szepessy Schaurek, unpublished).

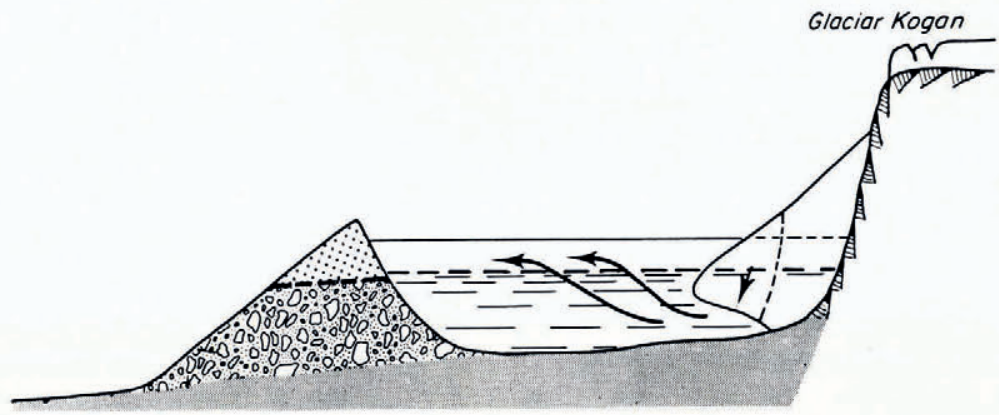

Fig. 8. Sketch of the event which produced the aluvion of Quebrada Los Cedros in 1949.

Nobody knew that the ice apron was calved under the lake surface: the water was probably at $4^{\circ} \mathrm{C}$ at depth and thus had melted the ice. The overhanging part, no longer sustained by the Archimedean force, broke and fell, producing big waves which overflowed and destroyed the gate. There was a fast regressive erosion of the moraine, formed almost exclusively of sand and pebbles. The stones of the sole were swept away, a waterfall formed, which widened while moving towards the lake. Finally the moraine around the gate failed and the big aluvion mentioned above took place. The level of the lake had lowered a further $21 \mathrm{~m}$, and since its surface was 300000 to $500000 \mathrm{~m}^{2}$, this gave a sudden discharge of 6 to $10 \times 10^{6} \mathrm{~m}^{3}$ of water.

\section{LAKES DISCHARGING THROUGH INFILTRATIONS}

Several lakes dammed by frontal moraines have no open outlet, Laguna Taulliraju, the lakes of Safuna and Laguna Parón being the main examples. The outflow is ensured by springs, the discharge of which varies according to the level of the lake. We have good measurements of discharge and levels at Laguna Parón for eight years from I 955 to I962, and incomplete data for 1966-69. Although the morainic dam of Parón is much larger than the other ones, and with a superimposed slender ice tongue on it, its constitution at the level of the aquifers should be a standard one. The springs are 60 to $75 \mathrm{~m}$ below the level of the lake.

As shown in Figure 9, the water level varies annually by $3.4 \pm 0.7 \mathrm{~m}$, having its highest value during the most rainy months (February or March, in general), and its lowest value at the end of the dry season (September or October, in general). The relation between level and discharge when both are increasing is given in Figure 10. (With the exception of the year i96o, 
GLAGIOLOGICAL PROBLEMS OF PERUVIAN LAKES. I
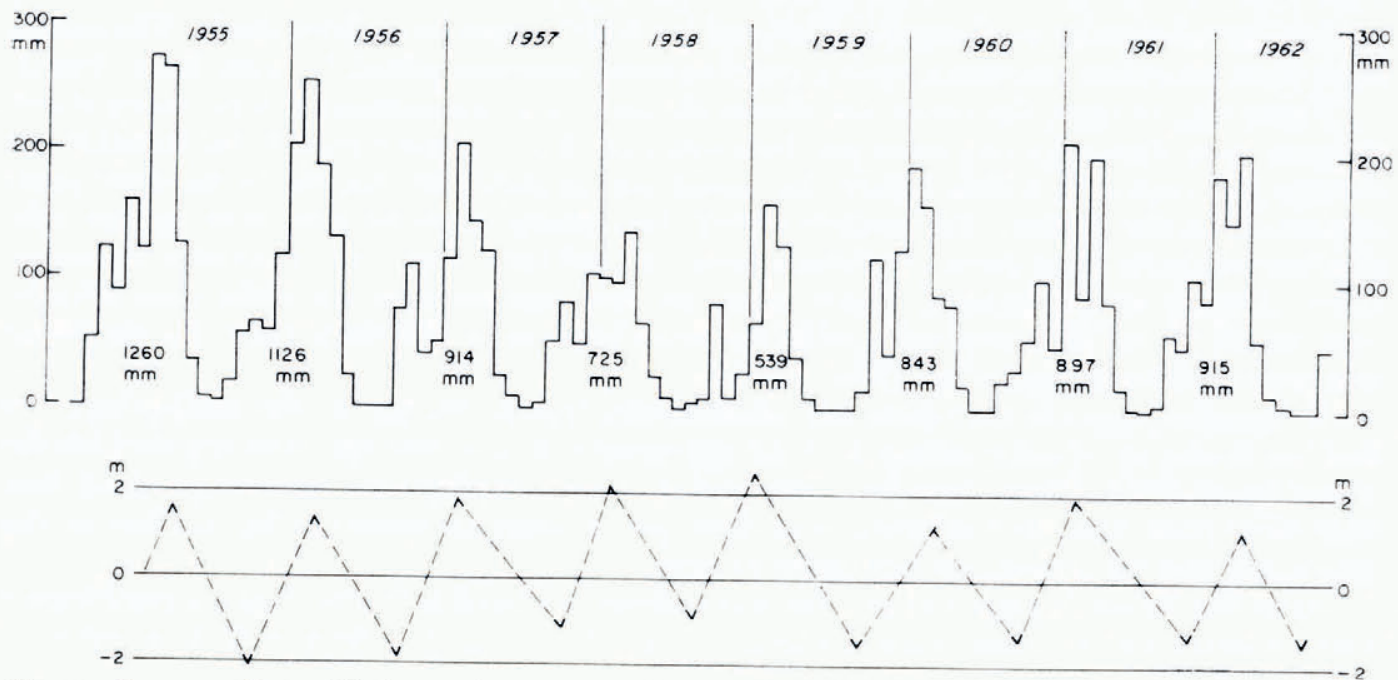

Fig. 9. Above: monthly precipitations at the western tip of Laguna Parón (4 $200 \mathrm{~m}$ a.s.l.). Below: highest and lowest levels of the lake.

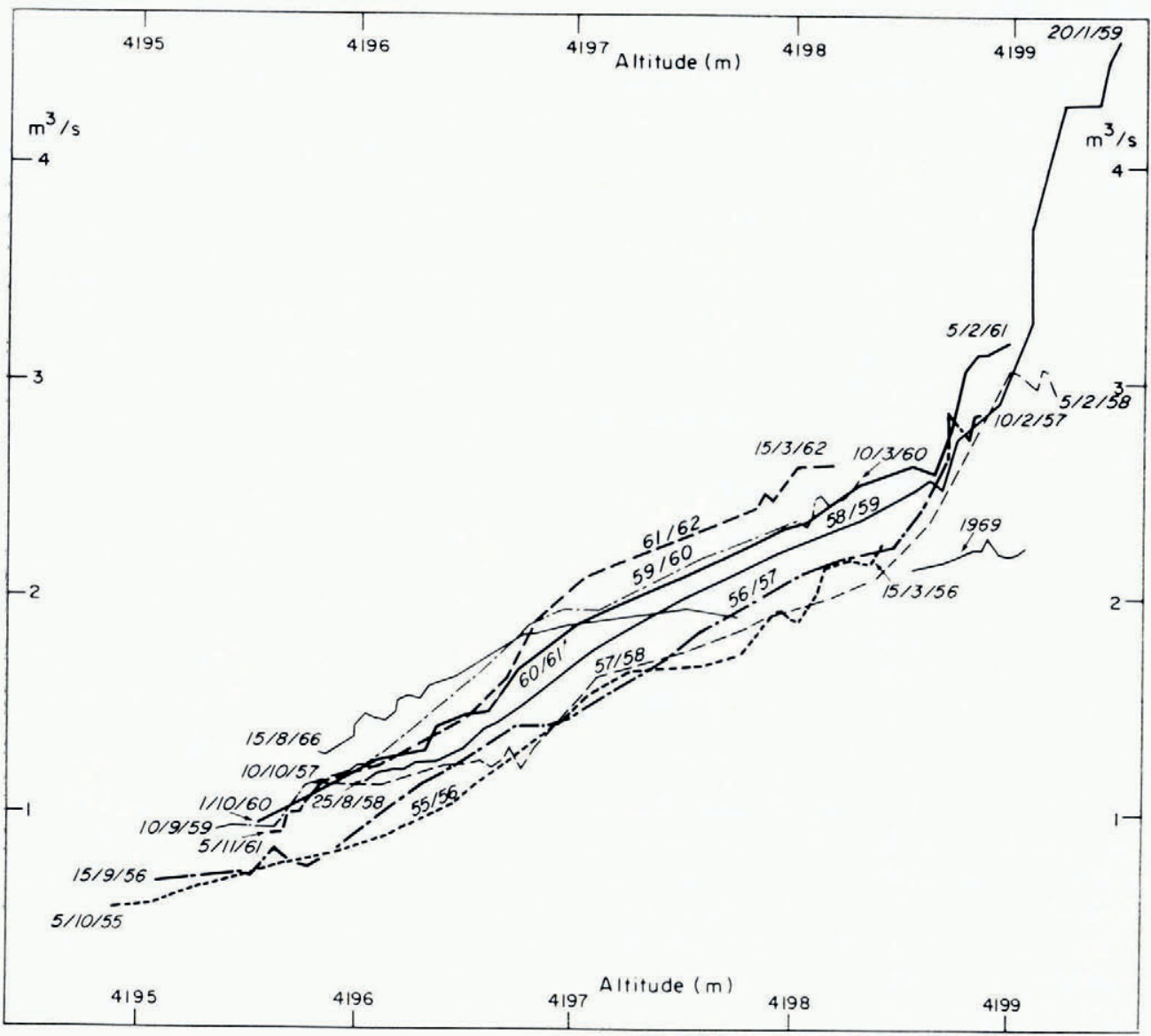

Fig. Io. Discharge of the springs from Laguna Parón versus level of the lake. Values for raising levels, smoothed by a running mean over 2 points. 
during the subsequent lowering the discharge is a little higher for a given level.) The curves have been somewhat smoothed, with a running mean over two points, to make them clearer.

From 1955 to 1957 , the curves are almost the same, with an increasing slope, which shows that the earth dam is getting more pervious upwards. For unknown reasons the lowest levels of 1957 and $195^{8}$ were a little higher than usual, and probably for this reason the subsequent maxima were also higher. The aquifers should then enlarge since the data from $195^{8}$ to 1966 give curves significantly above the former ones. In 1966 there must have been some unknown event (possibly an earthquake) which made the dam less pervious, since the slope became very small. So in February 1969 , with the same level as in February 196r, the discharge was only $2.2 \mathrm{~m}^{3} / \mathrm{s}$ instead of $3.2 \mathrm{~m}^{3} / \mathrm{s}$.

It therefore appears that there are continuously erratic changes in the infiltrations. In fact the drying up of some springs and the appearance of new ones has been reported by the observers of CPS. These variations may end in a catastrophic way, either by piping (the Hell Hole earth dam, in California, was destroyed by such an event), or by overflow of the free-board and the subsequent regressive erosion.

After the big earthquake of 1970 , the infiltrations increased at Parón, a spring discharging 5 1/s appeared $120 \mathrm{~m}$ below Laguna Llaca, and piping occurred at Safuna Alta, as reported below.

\section{Works at Laguna Parón}

Laguna Parón fills a U-shaped glacial valley. It covers $\mathrm{r} .6 \mathrm{~km}^{2}$ and encloses, at $4200 \mathrm{~m}$, $75 \times 10^{6} \mathrm{~m}^{3}$ of water which threaten Caraz $($ at $2285 \mathrm{~m})$ and the hydroelectric power-station of the CPS at Cañon del Pato. It has been reported how it was a mere chance that no disaster took place during the rupture of Artesoncocha in I95I. During the rainy season the free-board was less than $2 \mathrm{~m}$. So in $195^{2}$ the CCLCB raised the free-board by $2.6 \mathrm{~m}$ with a small earth dam, traversed by a provisional wooden duct $20 \mathrm{~m}$ long. (Today this wooden duct still exists, but it is rotten and filled in with earth.) The same year an expert from the U.S.A., Dr P. D. Trask (1953) indicated the only safe way to lower the water level: by digging a tunnel about $\mathrm{I} \mathrm{km}$ long within the cliff of fair granodiorite, on the right bank (northern side).

Although above Laguna Parón Artesoncocha and Chacrucocha are empty by now, and other small lakes in formation may be emptied, the danger of big rockfalls or icefalls from Huandoy or Aguja Nevada into the lake always exist, as well as the danger of piping. The works to be done were expensive. They were estimated in 1963 to amount to U.S. $\$ 786$ ooo, as detailed below (CPS, unpublished):

\begin{tabular}{lr} 
Exploratory coring of the rock and soil mechanics & $\$ 44$ ooo \\
Earth road $37 \mathrm{~km}$ long & 287 ooo \\
Camp, engineer's house, telephone line, generator set & 50 ooo \\
Digging of the tunnel & 200 ooo \\
Revetment of the tunnel & 66 ooo \\
Gates and subsidiary works & 139000 \\
\cline { 2 - 2 } & Total $\$ 786$ ooo
\end{tabular}

Nevertheless with a safe drainage, Laguna Parón could be used for water storage during the dry season, and the investment would be profitable. So the works were agreed in 1968 , an access road made the following year, together with the exploratory works. One of us (B.S.) even dived to a depth of $60 \mathrm{~m}$ in the lake with professional Peruvian divers to inspect closely the future point where the tunnel will come out, a world record at this altitude (4200 m) (Jeanneau, I969). When the r970 disaster took place the tunnel had been dug. Only the concrete lining, the gate, the last $50 \mathrm{~m}$ of tunnel and the final delicate shot to debouch into the lake remained to be done. More urgent needs have prevented the works since then. 


\section{Works at Laguna de Safuna Alta}

In 1969 Safuna Alta was the most dangerous lake of Cordillera Blanca. $4.9 \times 10^{6} \mathrm{~m}^{3}$ of water were locked between a steep frontal moraine and the glacier. The outer slope of the moraine is $35^{\circ}$, the inner slope $45^{\circ}$. The maximum depth of the lake was $80 \mathrm{~m}$, its surface, at $436 \mathrm{I} \mathrm{m}$, stood $18 \mathrm{~m}$ below the lowest point of the moraine. Several springs, 6 o to $\mathrm{ro} 8 \mathrm{~m}$ below the surface of the lake, ensured the outflow.

How the moraine and the bottom of the lake were explored is dealt with in Lliboutry and others (1977). Here we report on the works done or projected.

First, in I 968-69, a tunnel was dug through the moraine, o.80 $\mathrm{m}$ above the level of the lake, in order to prevent the level from rising. The loose moraine was held in place by hoops of sectional iron each $0.7 \mathrm{~m}$ long, and a casing of concrete.

The lake being entirely surrounded by moraine or ice, it was not possible to dig any tunnels below the water level without first emptying the lake. To do this, powerful pumps, discharging $0.8 \mathrm{~m}^{3} / \mathrm{s}$, would be necessary, and, although the existing gallery may be used, they must raise the water by nearly $80 \mathrm{~m}$ at the final stage. To do this $400 \mathrm{~kW}$ must be available. To set up an electric line to Safuna would cost U.S. $\$ 560$ ooo, and to use generator sets $\$ 430$ ooo. The use of a turbine, propelled by the resulting waterfall, would lower this sum to $\$ 300$ ooo. Nevertheless the delicate problems of coupling the turbine and the pumps had to be solved.

While this project was being studied by Coyne et Bellier the big earthquake of 1970 happened. The whole morainic dam settled and moved. The sole of the existing tunnel, which was $0.80 \mathrm{~m}$ above the water level, was found just after the earthquake $0.20 \mathrm{~m}$ below, with water flowing out. Fourteen transverse cracks, up to $0.30 \mathrm{~m}$ wide had appeared in the casing of concrete, some being over the whole cross-section. The tunnel, perfectly straight before, was tilted: from one entrance, only three-quarters of the other entrance can be seen.

The springs poured normally, but with muddy water. In the subsequent days their discharge grew exponentially. Piping was happening. Fortunately, after the lake had

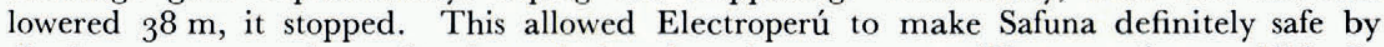
digging a new tunnel, $152.6 \mathrm{~m}$ long, during the subsequent years (Electroperú, unpublished).

MS. received I 8 May 1976

\section{REFERENCES}

Corporación Peruana del Santa. Unpublished. Laguna Parón. Programa y presupuesto de los trabajos de seguridad y regulación. [ 1953 ?, with copies of several internal reports written in $195^{\circ}-5^{2}$.]

Coyne et Bellier, Géoconseil. Unpublished [a]. Estudio de las cuencas Parón y Safuna en la Cordillera Blanca. Misión de Febrero 1967. [Preliminary report to Corporación Peruana del Santa.]

Coyne et Bellier, Géoconseil. Unpublished [b]. Informe de la misión efectuada en Mayo de 1969 por los Señores L. Lliboutry, J. Grador, A. Pautre. [Report to Corporación Peruana del Santa.]

Coyne et Bellier, Géoconseil. Unpublished [c]. Laguna Parón, informe sobre los reconocimientos. [Final report to Corporación Peruana del Santa, November i 969.$]$

Coyne et Bellier, Géoconseil. Unpublished [d]. Laguna Safuna, informe sobre los reconocimientos. [Final report to Corporación Peruana del Santa, November 1959.]

Coyne et Bellier, Géoconseil. Unpublished [e]. Lagunas de Safuna. Informe de la misión de Julio de 1967. [Preliminary report to Corporación Peruana del Santa.]

Electroperú. Unpublished. Memoria bienal del programa de glaciología y seguridad de lagunes r973-74. [Biennial report, Huaraz, 1975.]

Ghiglino, L. A. Unpublished. Informe sobre el aluvión de Los Cedros. [Corporación Peruana del Santa internal report, 22 December 1950.]

Jeanneau Gracey, J. I969. A 200 piés de profundidad en la Cordillera Blanca. Revista Peruana de Andinismo y Glaciologia, 1966-67-68, No. 8, p. 97-101.

Kauffmann Doig, F. 1973. Manual de arqueología peruana. Quinta edición. Lima, Ediciones Peisa.

Kinzl, H. 1940. La ruptura del lago glacial en la quebrada de Ulta en el año 1938. Boletín del Museo de Historia Natural Favier Prado, Vol. 4, No. 13, p. ${ }_{153-67 .}$ 
Kinzl, H. 1942. Gletscherkundliche Begleitworte zur Karte der Cordillera Blanca (Peru). Zeitschrift für Gletscherkunde, Bd. 28, Ht. I-2, p. I-19.

Kinzl, H. 1968. La glaciación actual y pleistocénica en los Andes Centrales. Colloquium Geographicum (Bonn), Bd. 9, p. 77-90. [Reproduced in Revista Peruana de Andinismo y Glaciología, 1969-70, No. 9, 2a Parte, p. I 7-24.]

Kinzl, H., ed. 1964. Begleitworte zur Karte 1 : 100 ooo der Cordillera Blanca (Perú) Südteil. Innsbruck, Universitätsverlag Wagner. (Wissenschaftliche Alpenvereinshefte, Ht. 17.)

Kinzl, H., and Schneider, E. 1950. Cordillera Blanca. Innsbruck, Universitätsverlag.

Lliboutry, L. A. [1975.] La catastrophe de Yungay (Pérou). [Union Géodésique et Géophysique Internationale. Association Internationale des Sciences Hydrologiques. Commission des Neiges et Glaces.] Symposium. Neiges et glaces. Actes du colloque de Moscow, août I971, p. 353-63. (IAHS-AISH Publication No. 104.)

Lliboutry, L. A., and others. 1977. Glaciological problems set by the control of dangerous lakes in Cordillera Blanca, Peru. III. Study of moraines and mass balances at Safuna, by L. [A.] Lliboutry, B. Morales Arnao and B. Schneider. Fournal of Glaciology, Vol. 18, No. 79, p. 275-90.

Lliboutry, L. A., and others. Unpublished. Evaluación de los riesgos telúricos en el Callejón de Huaylas, con vista a la reubicación de poblaciones y obras públicas, [by] L. [A.] Lliboutry, V. Mencl, B. Schneider, M. Vallon. [UNESCO report No. 2208 BMS-RD/SCE, Paris, 1970.]

Morales Arnao, B. 1966. The Huascarán avalanche in the Santa Valley, Peru. Union de Géodésie et Géophysique Internationale. Association Internationale d'Hydrologie Scientifique. Commission pour la Neige et la Glace. Division Neige Saisonnière et Avalanches. Symposium international sur les aspects scientifiques des avalanches de neige, 5-10 avril 1965 , Davos, Suisse, p. 304-15. (Publication No. 69 de l'Association Internationale d'Hydrologie Scientifique.)

Morales Arnao, B. I969. Las lagunas y glaciares de la Cordillera Blanca y su control. Revista Peruana de Andinismo y Glaciologia, 1966-67-68, No. 8, p. 76-79.

Morales Arnao, C. 1968. Andinismo en la Cordillera Blanca. Lima, Ediciones Turismo Andino.

Plafker, G., and others. 1971. Geological aspects of the May 31, 1970, Peru earthquake, by G. Plafker, G. E. Ericksen and J. Fernandez Concha. Bulletin of the Seismological Society of America, Vol. 6r, No. 3, p. 543-78.

Spann, H. J. 1947. Informe sobre el orígen de la catástrofe de Chavín de Huantar. Boletín de la Sociedad Geológica del Perú, No. 20, p. 29-33.

Szepessy Shaurek, A. Unpublished. Informe ... sobre las lagunas de la Cordillera Blanca. [Corporación Peruana del Santa, División de Recursos Hidráulicos, internal report, 1950.]

Trask, P. D. 1953. El problema de los aluviones de la Cordillera Blanca. Boletín de la Sociedad Geográfica de Lima, Vol. 7o, p. $1-75$

Welsch, W., and Kinzl, H. 1970. Der Gletschersturz vom Huascarán (Peru) am 31 Mai 1970, die grösste Gletscherkatastrophe der Geschichte. Zeitschrift für Gletscherkunde und Glazialgeologie, Bd. 6, Ht. 1-2, p. 181-92. 